медичної біології. Вісник проблем біології $i$ медицини. 2018. Вип. 3. С. 220-223.

4. Наказ МОН України від 19.12.2018 № 1419 «Про затвердження стандарту вищої освіти за спеціальністю 227 «Фізична терапія, ерготерапія» для першого (бакалаврського) рівня вищої освіти» [Електронний ресурс]. - Режим доступу: https://mon.gov.ua/storage/app/ media/vishcha-osvita/zatverdzeni\%20standarty/12/21/227-fizichna-terapiyaergoterapiya-bakalavr.pdf

5. Пішак В.П., Бажора Ю.І., Брагін Ш.Б., Воробець 3.Д., Дубінін С.І., Жегунов Г.Ф., Ковальчук Л.С., Корольов В.О., Костильов О.В., Кулікова Н.А., Піскун Р.П., Романенко О.В., Слесаренко О.Г., Стеблюк М.В., Федченко С.М. Медична біологія: Підручник / за ред. В.П. Пішака, Ю.І. Бажори. Видання 3-є. Вінниця: НОВА КНИГА, 2017. 608 с.

6. Романенко О.В., Кравчук М.Г., Грінкевич В.М., Костильов О.В. Медична біологія: Посібник 3 практичних занять / за ред. О.В. Романенка. 2-е вид. Київ «Медицина», 2020. 472 с.

7. Збірник завдань для підготовки до тестового екзамену 3 природничо-наукових дисциплін «Крок-1. Загальна лікарська підготовка» / Кол. авторів; За ред. В.Ф. Москаленка, О.П. Волосовця, I.Є. Булах, О.П. Яворовського, О.В. Романенка, Л.І. Остапюк. Київ: Медицина, 2004. 368 с.

DOI https://doi.org/10.30525/978-9934-26-173-2-18

\title{
РЕЗУЛЬТАТИ АНКЕТУВАННЯ ПІЛОТІВ ЩОДО ГОТОВНОСТІ ДО МІЖКУЛЬТУРНОЇ ВЗАЕМОДІї
}

\author{
Мартиненко Н. О. \\ аспірантка кафедри професійної педагогіки \\ та сочіально-гуманітарних наук \\ Льотна академія \\ Наиіонального авіаційного університету \\ м. Кропивницький, Україна
}

Міжкультурний склад студентів льотних закладів вищої освіти висуває перед освітньою системою комплекс проблем, пов'язаних не тільки 3 багатою кількістю мов і культур, але й 3 відмінностями етносів за характером та рівнем розвитку. Таким чином, стала гостро відчуватися проблема розробки нової концепції освіти, яка б дозволила 72 
враховувати інтереси всіх етнічних груп в освітньому процесі. Розробка концепції мультикультурної освіти $\epsilon$, на сьогодні, об'єктивною необхідністю в сучасному суспільстві.

Вітчизняні науковці авіаційної сфери наголошують на різних аспектах підготовки майбутнього авіаційного фахівця. О. Керницький у своєму дослідженні розглядає психологічну готовність пілота, тобто, за допомогою керування психоемоційним станом, майбутній пілот унеможливлює виникнення небезпечних ситуацій та конфліктів у екіпажі [2]. А. Дранко у своїх наукових пошуках зазначає основні недоліки у професійній підготовці авіафахівців та зауважує на актуальності професійної взаємодії та колективної роботи майбутніх пілотів [1]. Науковець Т. Плачинда наголошує на формуванні психічної та емоційної стійкості майбутніх фахівців [3].

Для визначення актуальності теми дослідження, ми провели анкетування професійних пілотів різних авіакомпаній України (УРГА, MAУ, Sky Up, Wind Rose). На запитання «Як Ви вважаєте, наскільки часто існує можливість виникнення непорозуміння з представниками інших культур у професії пілота?» $48 \%$ респондентів відповіли «інколи», $22 \%$ «часто» та $12 \%$ вважають, що непорозуміння «рідко» виникають.

У запитанні «3 Вашого особистого досвіду, наскільки готовим Вибули на початку своєї кар'єри працювати у мультикультурному середовищі?» пілоти повинні були оцінити особистісну готовність до роботи у багатонаціональній команді після закінчення навчання. 52\% надали відповідь «скоріше не готов», 28\% відповіли, що «скоріше готов, ніж не готов».

Проаналізувавши відповіді на питання «Як Ви вважаєте, що є важливим для успішної міжкультурної професійної взаємодії?» та «На Вашу думку, чи потрібні знання культурно-етнічних норм та особливостей представників інших культур?», ми відзначили, які саме чинники міжкультурної взаємодії є найважливішими у професійній діяльності пілотів: 42\% - достатня професійна підготовка; 24\% достатній досвід у професії; $28 \%$ - взаємоповага, знання традицій та особливостей поведінки представників різних націй. $54 \%$ опитаних чітко висловили свою думку стосовно культурно-етнічних норм та особливостей та вважають, що ці знання є важливою складовою для формування єдиної мультикультурної команди. Варто зазначити, що $80 \%$ опитаних відповіли на питання «Як на Вашу особисту думку, чи важливо уміти встановлювати сприятливий психологічний мікроклімат у команді?» одностайно «так».

Формування сприятливого психологічного клімату міжособистісних відносин постає у вигляді взаємовідносин серед членів екіпажу 
(співпраці, змагання, згуртованості, сумісності, дружби, злагоди). А також у вигляді якостей особистості спілкування пілотів у команді (товариськість, замкнутість, сором'язливість, скритність, самостійність, відповідальність, чесність). Тому відповіді на запитання «Які саме фактори, із перерахованих нижче, найбільше впливають на створення сприятливого психологічного мікроклімату?» можемо підсумувати: близько 38\% вважають, що «підтримка» та «довіра» дуже впливають на створення сприятливого мікроклімату; 26\% відповіли, що «єдність» достатньо впливає на клімат у команді; $12 \%$ вважають, що «сумісність» не суттєво впливає на створення мікроклімату.

На запитання «Чи враховуєте Ви цінності іншої культури при спілкуванні 3 представниками інших етносів?» 77\% 3 повагою відносяться до іншої культури. Цінності та поведінка людей, що належать до інших культур, зовсім не $є$ чимось непередбачуваним. Вивчення інших культур, їх особливостей, закономірностей їх функціонування та розвитку збагачує людину та трансформує ставлення до світу й різних націй та етносів, може кардинально змінити ставлення до життєвих ситуацій.

Запитання «Чи виникали у Вас конфліктні ситуації з представниками інших національностей у командній роботі?» дало нам змогу визначити, які саме конфліктні ситуації виникали у професійних пілотів у складі мультикультурних екіпажів, адже $42 \%$ відповіли «так». Ми акцентували такі відповіді: професійна нерівність (командир-іноземець); гендерна нерівність (якщо у складі екіпажу жінка-пілот); ставлення іноземців, як до менш досвідчених; зверхнє ставлення. Конфліктна ситуація може виникнути на підгрунті розбіжностей в тому чи іншому питанні. При цьому, в кожного члена команди може бути власна точка зору стосовно питання. Тому, з відповідей на питання «Як Ви вважаєте, чи важливо формувати конфліктостійкість у майбутнього пілота?» та «Чи вважаєте Ви толерантність (терпимість) до інших людей однією 3 основних якостей професійного пілота для міжкультурної взаємодії?» ми визначили, що конфліктостійкість та толерантність (терпимість) є дуже важливою якістю професіонала, 58 \% відповідей «так».

Отже, ми визначили, що проблема готовності пілотів до міжкультурної взаємодії $є$ дуже актуальною та вважаємо, що розробки та пропозиції нашого дослідження допоможуть майбутнім професіоналам уникнути проблем та конфліктів у спілкуванні та мультикультурній команді. 


\title{
Література:
}

1. Дранко А. А. Формування професійної взаємодії майбутніх пілотів цивільної авіації у процесі наземної практичної підготовки: дис. ... канд. пед. наук: 13.00.04. Кропивницький, 2018. 224 с.

2. Керницький О. М. Методика формування психологічної готовності курсантів-льотчиків до льотної діяльності: автореф. дис. ... канд. пед. наук: 13.00.02. Харків, 2005. 17 с.

3. Плачинда Т. С. Формування емоційної стійкості майбутніх пілотів засобами фізичної і психофізіологічної підготовки / T. С. Плачинда // Вісник Національного авіаційного університету : зб. наук. праць. К.: НАУ, 2011. № 2 (47). С. 170-176.

DOI https://doi.org/10.30525/978-9934-26-173-2-19

\section{ОСОБЛИВОСТІ САМОСТІЙНОЇ РОБОТИ СТУДЕНТІВ МЕДИКІВ 3 ДИСЦИПЛІНИ «МЕДИЧНА ХІМІЯ» В УМОВАХ БОЛОНСЬКОЇ СИСТЕМИ}

\author{
Нечитайло Л. Я. \\ кандидат біологічних наук,
}

асистент кафедри біологічної та медичної хімії ім. ак. Г. О. Бабенка Івано-Франківський національний медичний університет

Кривов'яз О. С.

здобувач $P h D$,

асистент кафедри біологічної та медичної хімї ім. ак. Г. О. Бабенка Івано-Франківський національний медичний університет

Данилів C. I.

кандидат біологічних наук,

асистент кафедри фармацевтичного управління, технологї ліків

та фармакогнозії

Івано-Франківський національний медичний університет

м. Івано-Франківськ, Украӥна

Навчальна дисципліна «Медична хімія» закладає основи вивчення студентами таких медико-біологічних дисциплін як: фізіологія, патофізіологія, біологічна хімія, фармакологія, а також деяких клінічних, гігієнічних дисциплін та екології. Курс медичної хімії в ІФНМУ вивчають студенти медичного та стоматологічного факультетів 